\title{
Analysis of Government Policy on Disaster Management System
}

\author{
Tb. Ace Hasan Syadzily ${ }^{1}$ \\ \{ace.hasan@gmail.com ${ }^{1}$ \} \\ Faculty of Economics and Business, Syarif Hidayatullah University Jakarta, Indonesia ${ }^{1}$
}

\begin{abstract}
This study aims to analyze government policies on disaster management systems in Indonesia. The research method used is a literature study. The data sources come from primary law and previous research that is relevant to the investigation. The results reveal that for disaster risk reduction, the policy needs to be revised. There are various types of disasters, avoiding policy ambiguity, and technological developments that have obstacles and challenges to implementing these policies, especially in the Government Regulation Law Number 24 of 2007 concerning Disaster Management. There are five main aspects of the disaster management system that require renewal, namely institutional aspects, budgetary aspects, disaster management implementation aspects, policy aspects, and disaster types aspects. These findings also indicate that to increase joint responsibility, especially the government. So that it is more focused and integrated into disaster management, government policies must be continuously updated. This research contributes to improving disaster management and helps guide policies for stakeholders so that the implementation of disaster resilience policies becomes more effective and efficient.
\end{abstract}

Keywords: Policy; Disaster Management System

\section{Introduction}

Based on data from the National Disaster Management Agency (BNPB), in recent decades, all regions of Indonesia have faced disasters. For example, the four major disasters that have hit in 2018-2020, the earthquake in the West Nusa Tenggara region, the earthquake and tsunami in Southeast Sulawesi, the Sunda Strait Tsunami, and the 2019 Coronavirus Disease pandemic (COVID 19). From the disasters in West Nusa Tenggara, Central Sulawesi, and the Sunda Strait area, 4,814 people have died, and 592 people are declared missing. Meanwhile, until 2020, as many as 135,123 people have contracted the Covid-19 pandemic, 89,618 people have recovered, and 6,021 people have died. It indicates that every district/city is vulnerable to disasters. It's just that in different levels of qualifications and standards. Therefore, the government in the disaster management system certainly has the policy to deal with this situation. What is clear, as in the preamble of the 1945 Constitution, states that "the safety of the people is the highest law as the state aims to protect the entire nation and all blood Indonesia [1]."

Disaster management is a shared responsibility of all members of the community. Previous research revealed that low shared responsibility indicates the failure of disaster management discourse. Research suggests that an incomplete normalization process is the cause of failure in implementing disaster management policies. What is clear is that disaster policy is a social contract that articulated as a form of socio-economic resilience linked to community powerlessness [2]. Policies in disaster management systems can adopt the concept 
of resilience as the main objective of emergency policies and disaster management. It can be understood that policies should be able to overcome this powerlessness instead of being ineffective and right on target.

Previous studies raised the same problem about the benefits of policy analysis on disaster management systems in various parts of the world. The bureaucracy is considered a key instrument of more modern public administration. It is because an efficient bureaucratic machine has a vital role in public affairs, especially in implementing policies and programs and providing available services [3]. In China, by conducting policy analysis, it can be seen how a pattern of policy change on disaster management can be identified [4]. That way, the risk of future disasters can be avoided. The implementation of disaster management policies in Malaysia has an impact on the governance framework. In other words, significant strategic changes and the introduction of an appropriate framework for disaster management can improve the performance of relevant agencies involved in disaster management [5]. Recognizing the importance of effective policies, systematic steps to implement national frameworks must link economic, community, environmental, and development concerns as a whole for better response and disaster mitigation [6].

Pada dasarnya regulasi pemerintah saaat ini telah aktif dan cepat tanggap dalam They are facing various disasters. The implementation of Law Number 24 of 2007 concerning Disaster Management can show the progress that the government has made. For example, in policies and institutions for managing natural and non-natural disasters, understanding risks and disaster early warning systems, utilizing science and education, and government preparedness for disaster. Previous research states that policy in the expected implementation has several shortcomings and weaknesses that must be corrected immediately [7]. It is not without reason that there are technological developments, Indonesia's archipelagic region, and densely populated people, as well as various types of disasters that require policies which of course deal with different [8]. Also, policies that have specifically revised can improve the performance of disaster management in a more prosperous, targeted, and integrated manner [9][10]. Indicate that there is a need to revise Law Number 24 of 2007 concerning Disaster Management. This policy revision is part of the improvement of disaster management by Commission VIII of the House of Representatives of the DPR RI) to work more effectively and efficiently.

\section{Methods}

This study aims to analyze government policy problems in the disaster management system that occurs in Indonesia. By using a literature study research method, researchers attempted to explore policies and procedures for disaster management during the period 20182020. In particular, the Covid-19 Pandemic response system. the content analysis method, identified important documents are then studied and recorded to determine the contribution and support that these documents provide to disaster management in Indonesia.

This literature study explores the central and crucial material in government regulations and policies, especially in disaster management systems. Primary legal data comes from Law Number 24 of 2007 concerning Disaster Management, which takes effect after it promulgated in the State Gazette of the Republic of Indonesia of 2007 Number 66 and an explanation of Law Number 24 of 2007 concerning Disaster Management in Supplement to the State Gazette of the Republic of Indonesia Number 4723 Law Meanwhile. Secondary data comes from the Disaster Management Agency, the Central Bureau of Statistics, and previous research by the research objectives. 


\section{Result and Discussion}

\subsection{Disaster Management Policy in Indonesia}

The direction of the disaster management system developed in Indonesia for the community is to make Indonesia ready for disasters. It does as a form of readiness from the government to anticipate a similar major disaster in Indonesia. The risks associated with disasters that must be faced and disaster management can have an impact on the disaster network [11]. The point is that disaster management policies are made based on disasters that occur, and it can be understood that the two are interrelated. Disaster management must also comply with applicable regulations, particularly the principles and principles contained in Law Number 24 of 2007 concerning Disaster Management CHAPTER II Foundation, Principles and Objectives of article 3 paragraph (1) and (2),

"Paragraph (1) Disaster management, as referred to in Article 2 shall be based on: a.

Humanity; justice; equal position in law and government; balance, harmony and harmony; legal order and certainty; togetherness; environmental sustainability; and science and technology. Paragraph (2) Principles in disaster management as referred to in Article 2, namely a. Fast and precise; $b$. Priority; $c$. Coordination and integration; $d$. Efficient and effective; e. Transparency and accountability; f. Partnership; $g$. Empowerment; h. Non-discriminatory and i. Nonprolition."

Based on this article, it stated that policies must be supported by good governance, principles and principles so that these policies can implement more effectively [12]. So it's not just making revisions but also making changes to governance. The policy framework for a disaster management system must be based on an understanding of risk, not only at an ideological level. The main gaps and challenges identified include; 1) still weak coordination, cooperation, and linkages between sectors and institutions; 2) lack of skills in assessing postdisaster losses and needs; 3) lack of a strategic research agenda; 4) there is no agreement on terminology, and 5) limited coordination between stakeholders [13].

More profoundly, Surianto (2019) also revealed that there are four priority actions in the framework of a disaster management system that can be implied, namely: 1) understanding disaster risk; 2) strengthening disaster risk management; 3) investing in resilience to reduce disaster risk; and 4) increasing disaster preparedness as a form of effective response in building back better in the context of post-disaster recovery [13]. Of course, must be based on the objectives of disaster management as contained in Article 4,

"Disaster management aims to: $a$. Protecting the community from the threat of disaster 'b. Carry out existing laws and regulations; $c$. Ensuring the implementation of disaster management in a planned, integrated, coordinated, and comprehensive manner; $d$. Appreciate local culture; $e$-Building public and private participation and engagement; $f$. Encourage the spirit of cooperation, solidarity, and generosity; and g. Creating peace in the life of society, nation, and state."

It is clear that in revising policies on disaster management systems, it must be based on the objectives of disaster management as already described. The central government and regional governments have the responsibility for its implementation. In this case, the National Disaster Management Agency has a role as stated in CHAPTER IV Institutional Section One National Disaster Management Agency Article 12,

"The National Disaster Management Agency has functions including a. Formulation and stipulation of policies for disaster management and handling refugees by acting quickly 
and precisely and effectively; and $b$. Coordinating the implementation of disaster management activities in a planned, integrated, and comprehensive manner."

There are three keys to success in implementing disaster management policies, namely 1) there is a balance between personal and public interests; 2) private participation; 3) overcoming barriers to policy implementation and effective implementation [9]. Note that post-disaster learning and adaptation does not occur at the local level [14]. So that success in implementing community-based policies must be resilient in practice.

There are five primary and crucial items in the Draft Law (RUU) on Disaster Management in Indonesia. First, from the institutional aspect. The Disaster Management Bill reinforces for BNPB to form regional work units (satker) to implement disaster management in the regions according to the needs and laws and regulations. The purpose of establishing the satker is to accelerate the implementation of disaster management and cut the flow of bureaucracy. Therefore, in carrying out their duties and functions, BNPB and the Regional Disaster Management Agency (BPBD) are given easy access during a state of emergency disaster to speed up the bureaucratic process. This bill will answer the doubts of several groups who think that this bill weakens BNPB and BPBD.

In implementing disaster management, BNPB and BPBD can mobilize and involve TNI Soldiers and Members of the Police. About other institutions, the Disaster Management Bill stipulates explicitly and firmly that the BPBD must be led by the head of the agency, not a daily executive. The Head of BNPB and BPBD can also serve by Civil Servants (PNS), TNI Soldiers, and Members of the Police. The Disaster Management Bill also removes the BNPB steering element.

Second, the budget aspect. Being in a disaster-prone zone forces the Government to allocate disaster management funds. However, the funds prepared are still insufficient to handle disasters. For example, in the 2016 Draft State Budget, the Government plans to provide a standby fund for BNPB of IDR 1.18 trillion, which is on call and ready to be used at any time if there is a request from BNPB. This budget was very far from the total need for disaster management throughout Indonesia, was estimated at Rp. 15 trillion per year. The low allocation of funds for disaster management shows that the Government has not made disaster management a development priority. The figures shown in the RAPBN seem to be a form of "formality" for fulfilling the demands of disaster issues, which often occur, rather than databased budgeting for disaster hazards. In 2019, the government did increase the disaster budget from IDR 7 trillion to IDR 15 trillion. However, if in perspective, that figure is only $0.65 \%$ of the 2019 State Budget of IDR 3,210 trillion

The Disaster Management Bill regulates something new from the previous law, namely allocating funds for disaster management. If, in the last Law, the regulation on budget allocation states as "The government and local governments allocate disaster management budget adequately." This bill mandates that the central government allocates a disaster management budget of $2 \%$ (two percent) of the State Revenue and Expenditure Budget (APBN). Not only for the central government, but this bill also requires regional governments to allocate $2 \%$ (two percent) of the total provincial budget (APBD) for disaster management. This arrangement formulates considering the vulnerability of disasters that often occur and require a large account. This arrangement is also intended as mandatory spending and encourages local governments not to always "depend" on the central government.

Third, aspects of disaster management. In the previous Disaster Management Law, it stated that the implementation of disaster management consists of three stages, including predisaster, during disaster emergency response, and post-disaster. In the Disaster Management Bill, these stages will change to pre-disaster, disaster emergency, and post-disaster. 
Implementing disaster management in disaster emergencies includes emergency preparedness, emergency response, and emergency transition to recovery. In this aspect of implementation, the Disaster Management Bill also strengthens BNPB - both in coordination, command, and implementing functions - in handling disasters in more than one region.

Fourth, the policy aspect. This bill focuses on the distribution of mega-projects currently being worked on by the Government that have the potential to cause disaster. Therefore, this bill will "force" the executors of these large projects to complete disaster risk analysis documents so that the Government can control disaster mitigation measures. This law intends to stipulate the requirement that any development activity with high risk and causing disaster must be equipped with a disaster risk analysis.

Fifth, the type of disaster. The Draft Law on Disaster Management adds various kinds of disasters, both natural and non-natural. For the kind of natural disaster, liquefaction, land movement, tidal wave, extreme climate, extreme weather, dangerous sea waves, abrasion, and celestial bodies added. Meanwhile, for non-natural disasters, pandemic disasters, forest fires, land fires, residential area fires, pests, and transportation accidents are added.

Those are the five aspects that become the central and crucial material in the Disaster Management Bill. Disaster management, especially when facing COVID 19 at the moment, actually requires strengthening institutional management and coordination between the Central and Regional Governments. Previous studies have made it clear that the weakest aspect of the Law and Policy Framework of a disaster management system is that there are no clear guidelines for local government [15].

Therefore, this bill must be clear and able to strengthen state agencies responsible for disaster management. Collaboration between the government and the community in disaster management activities is also needed as a key to professionalism in disaster management activities at both the national and provincial, and municipal levels. Because there seems to be a limitation on one authority [16]. As explained in CHAPTER V Community Rights and Obligations Part Two Community Obligations Article 27,

"Everyone is obliged to a. Maintain a harmonious social life of the community, maintain balance, harmony, harmony, and preserve environmental functions; $b$. Carry out disaster management activities, and c. Provide the correct information to the public regarding disaster management."

Also, disaster management requires the convenience of mobilizing resources and establishing disaster management centers in disaster-prone areas. We hope that this bill can go passe immediately to become a new legal umbrella in disaster management, especially COVID 19. This Disaster Management Bill is an effort to present comprehensive regulations in dealing with increasingly religious and complex disasters.

\section{Conclusion}

Based on the findings and discussion, it revealed that government policies in the disaster management system require specific revisions. Five main aspects that need novelty, namely: 1) institutional aspects aimed at accelerating the implementation of disaster management and the current bureaucratic flow; 2) more good disaster management aspects; 3) aspects of disaster management including emergency, disaster response, and emergency transition to recovery; 4) parts of policies capable of controlling disaster mitigation measures; and 5) more varied aspects of disasters, such as the types of liquefaction and pandemic disasters. 
Theoretically, research expected to be able to contribute to disaster management systems to be more effective and efficient. Research reveals that this can be done by updating the five materials. In practical terms, this research-based on science, particularly in terms of global disaster management law and policies.

\section{References}

[1] Badan Nasional Penanggulangan Bencana (BNPB), "Pusat Data, Informasi, dan Penanggulangan Bencana Tahun 2018-2020,” BNPB.go.id, 2020. [Online]. Available: https://www.bnpb.go.id/.

[2] C. Atkinson and S. Curnin, "Sharing responsibility in disaster management policy," Prog. Disaster Sci., vol. 7, no. 3, p. 100122, 2020.

[3] N. I. Sarker and M. Wu, "Bureaucracy in Bangladesh: A Disaster Management Perspective," Glob. Encycl. Public Adm. Public Policy, Gov., no. August, pp. 1-5, 2019.

[4] Q. Zhang, Q. Lu, D. Zhong, and X. Ye, "The Pattern of Policy Change on Disaster Management in China: A Bibliometric Analysis of Policy Documents, 1949-2016," Int. J. Disaster Risk Sci., vol. 9, no. 1, pp. 55-73, 2018.

[5] S. Khairilmizal, M. F. Hussin, K. Ainul Husna, A. R. Hussain, M. H. Jusoh, and A. A. Sulaiman, "Implementation of disaster management policy in Malaysia and its compliance towards international disaster management framework," Inf., vol. 19, no. 18A, pp. 3301-3306, 2016.

[6] A. Jha, R. Basu, and A. Basu, "Studying Policy Changes in Disaster Management in India: A Tale of Two Cyclones," Disaster Med. Public Health Prep., vol. 10, no. 1, pp. 42-46, 2016.

[7] K. Alexander, A. M. G. Jarman, and U. Rosenthal, "Inter-organizational policy processes in disaster management," Disaster Prev. Manag. An Int. J., vol. 4, no. 2, pp. 20-37, 1995.

[8] D. A. Puspito Sari, I. Listiyowati, T. Nefianto, and Lasmono, "The Discrepancy between the Programs and Disaster Management Policy in Klapanunggal District, Bogor, West Java," IOP Conf. Ser. Earth Environ. Sci., vol. 135, no. 1, 2018.

[9] S. Siriporananon and P. Visuthismajarn, "Key success factors of disaster management policy: A case study of the Asian cities climate change resilience network in Hat Yai city, Thailand," Kasetsart J. Soc. Sci., vol. 39, no. 2, pp. 269-276, 2018.

[10] S. Hoossein, R. Tandlich, K. Whittington-Jones, R. Laubscher, P. Madikizela, and B. M. Zuma, "IINTERNATIONAL PERSPECTIVES: Disaster Management Policy Options to Address the Sanitation Challenges in South Africa," J. Environ. Health, vol. 78, no. 7, pp. E1-E7, 2016.

[11] M. Shimizu and A. L. Clark, "Interconnected Risks, Cascading Disasters and Disaster Management Policy: A Gap Analysis," GRF Davos Planet@Risk, vol. 3, no. 2, pp. 260-270, 2015.

[12] S. Khairilmizal, M. F. Hussin, A. I. Mohd Yassin, A. R. Hussain, M. H. Jusoh, and M. H. Kasri, "Policy on disaster management in Malaysia: the need of supporting governance," Adv. Sci. Lett., vol. 22, no. 12, pp. 4213-4215, 2016.

[13] S. Surianto, S. Alim, R. D. Nindrea, and L. Trisnantoro, "Regional policy for disaster risk management in developing countries within the sendai framework: A systematic review," Open Access Maced. J. Med. Sci., vol. 7, no. 13, pp. 2213-2219, 2019.

[14] L. Drennan and L. Morrissey, "Resilience policy in practice - Surveying the role of community based organisations in local disaster management," Local Gov. Stud., vol. 45, no. 3, pp. 328-349, 2019.

[15] D. van Niekerk, "A critical analysis of the South African Disaster Management Act and Policy Framework," Disasters, vol. 38, no. 4, pp. 858-877, 2014.

[16] I. Raungratanaamporn, P. Pakdeeburee, A. Kamiko, and C. Denpaiboon, "Governmentcommunities Collaboration in Disaster Management Activity: Investigation in the Current Flood Disaster Management Policy in Thailand,” Procedia Environ. Sci., vol. 20, pp. 658-667, 2014. 